\title{
Neotyphodium infection and hybridisation as a function of environmental variation
}

\author{
CYD HAMILTON $^{1}$ and STAN FAETH \\ ${ }^{1}$ Arizona State University, School of Life Sciences \\ Cyd.Hamilton@asu.edu
}

\begin{abstract}
Neotyphodium is an asexual, vertically transmitted, obligate fungal endosymbiont infecting cool-season grasses such as Arizona fescue. The relationship between Neotyphodium and several native grass hosts ranges from antagonistic to mutualistic. One theory that may explain how Neotyphodium infection is maintained despite inconsistent mutualistic benefit to the host is the bounded hybrid superiority hypothesis. This hypothesis argues that hybrids are more fit than non-hybrids in response to some environmental stresses. Neotyphodium infects hosts in both hybrid and non-hybrid forms. We tested the possibility of hybrid superiority in depauperate habitats (low soil water and nitrate) by quantifying the types and frequency of host infections (uninfected, hybrid-infected and non-hybrid-infected), and the quality of resources available between three host populations. A second theory, the geographic mosaic theory of coevolution, may also explain different symbiotic outcomes at the population level in response to variation in abiotic and biotic population characters. We provide cursory support for both hypotheses.
\end{abstract}

Keywords: geographic mosaic theory of coevolution, hybrid, Festuca, Neotyphodium, symbiosis, mutualism, bounded hybrid superiority

\section{Introduction}

The geographic mosaic theory of coevolution postulates that low migration rates coupled with unique selection pressures at the population level result in specialised coevolutionary trajectories (Thompson 1999; Thompson \& Fernandez 2006). For symbiotic interactions, local selection pressures may cause variation in outcomes. If migration is low or variable between coevolving organisms, then a geographic mosaic results with some populations well-adapted to their symbiont and others maladapted. In addition, differential rates in gene flow as well as variation in interspecific interactions can lead to variable symbiotic outcomes between and within populations (Gomulkiewicz et al. 2003). Previous

Figure 1 Population percentages for each infection type; $\mathrm{E}-$ = uninfected hosts, $\mathrm{H}=$ hybrid infection hosts, $\mathrm{NH}=$ nonhybrid infected hosts.

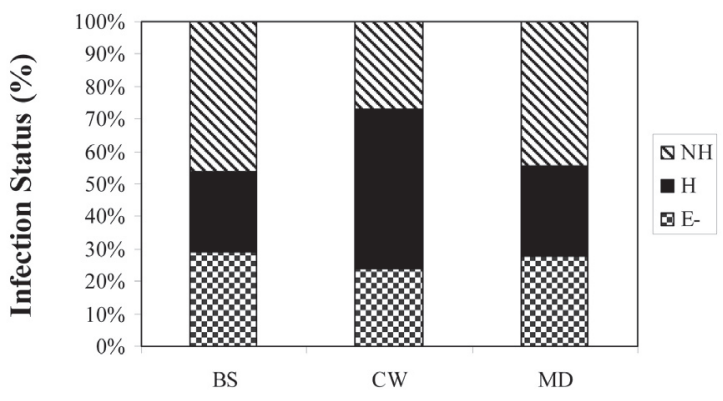

Population research by Sullivan \& Faeth (2004) found very low gene flow in Neotyphodium spp. among host populations of Arizona fescue. Since $F$. arizonica (AF) is a long lived facultative host that relies on wind pollination, genotypic mismatching is a plausible expectation. Thus, we predicted that unique infection frequencies, endophyte haplotypes, and plant performance may be associated with key abiotic parameters creating a mosaic of interspecific interactions. Specifically, we predicted that populations with the lowest soil moisture should have the highest infection frequencies if endophyte infection enhances host performance in drought conditions as determined by Morse et al. (2002, 2007). We also expected hybrids to be comparatively more prevalent in depauperate habitats (see below). Regardless of the neutral or negative effects of endophyte infection in Festuca arizonica, host grass populations retain high infection frequencies ranging from $60 \%$ to $100 \%$ (Schulthess \& Faeth 1998).

Arizona fescue can be infected by two 'forms' of Neotyphodium, hybrid $(\mathrm{H})$ or nonhybrid $(\mathrm{NH})$. Neotyphodium hybrids result from mutual infection of the host by Neotyphodium sp. and Epichloë species (Schardl et al. 1994 ; Selosse \& Schardl 2007; Tsai et al. 1994). Including the possibility of three infection types, (uninfected, hybrid, or nonhybrid infected) provides an opportunity to investigate the bounded hybrid superiority (BHS) hypothesis (Arnold 2004). Hybridisation infuses new genetic variation thought to be adaptive to the endophyte-host symbiosis (Selosse \& Schardl 2007). The BHS hypothesis predicts that hybrids will be favoured, and therefore probably more frequent, in marginal habitats (Brasier et al. 1999; Brasier et al. 1998; Cruzan \& Arnold 1993; Ellstrand \& Schierenbeck 2006; Rieseberg 1995; Rieseberg et al. 2003) due to the expression of intermediate or mixed parental phenotypes.

To determine whether infection and, in particular, hybrids were correlated with environmental factors at the population level, we selected three $F$. arizonica (AF) populations and measured the following biotic and abiotic population characters: (1) soil moisture (growing season defined as May (spring) - September

Figure 2 Average available soil $\mathrm{NO}_{3}^{-}$for summer months 2006 (May through July and August through October 2006) for each Arizona population. Nitrate in $\mathrm{mg} / \mathrm{L}$ of resin extraction.

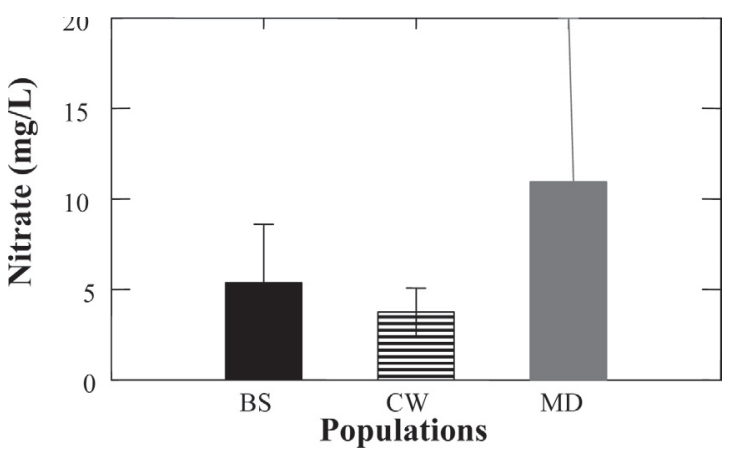


Figure 3 Percent soil moisture per population for May and August of 2006.
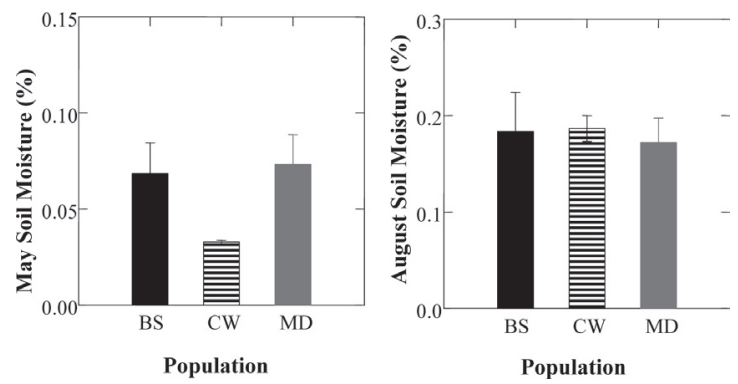

(autumn); (2) available soil nitrate $\left(\mathrm{NO}_{3}^{-}\right)$; (3) host height; (4) production of viable seeds by host; (5) frequencies of uninfected (E-), hybrid infected $(\mathrm{H})$, non-hybrid infected $(\mathrm{NH})$ hosts; and (6) host abundance (calculated as the ratio of hosts to total plant count per population)

\section{Methods}

Festuca arizonica (Vasey), Arizona fescue, is in the subfamily Pooidaceae; it is a dense, perennial bunchgrass that reproduces via seed and is incapable of clonally reproducing (USDA 1988). It is native to semi-arid ponderosa pine-bunchgrass communities found at elevations greater than $2000 \mathrm{~m}$. Three AF populations were involved in this study, Clint's Well (CW), Buck Springs (BS), and Merritt Draw (MD). These sites are characterised by yearly droughts, and two rainy seasons (winter and summer) with annual precipitation ranging from 500 to $800+\mathrm{mm}$.

The three Arizona populations were randomly sampled for percent soil moisture and amount of available soil $\mathrm{NO}_{3}^{-}$in May and August of 2006. Forty plants from each population were randomly sampled and identified for infection status and 'type' ( $\mathrm{H}$ versus NH endophyte infection). Extraction of fungal DNA (Promega Wizard Plant DNA Extraction Kit) and use of primers specific to Neotyphodium spp. (Dombrowski 2006 \#327) differentiated E-, H, and $\mathrm{NH}$ infection types for all plants samples. Twenty plants were divided in the field, tagged, and planted for transport to an ASU greenhouse. Two-thirds of the original plant remained in the field (also tagged). Seeds were identified as viable using tetrazolium stain as described by Sawma \& Mohler (2002).

Measures of available soil $\mathrm{NO}_{3}^{-}$were determined using resin bags. Four resin bags were planted to a $10 \mathrm{~cm}$ depth and placed randomly within each of the three populations as per Köchy and Wilson (2001). All 12 resin bags were kept in the field for 60 days. A first set of 12 bags (four per population) was planted in June 2006 and removed the following August; a second set was planted in August 2006 and removed the following October.

\section{Statistics}

Significant differences between the three host infection types (E-, $\mathrm{H}$ and $\mathrm{NH}$ ) at the population level were determined using contingency table analysis. Analysis of variance (ANOVA) was used to compare host infection identity with host phenotypes (height and percent viable seed produced) and population characters (amount of available soil $\mathrm{NO}_{3}^{-}$, percent soil moisture, host abundance). All percentages were arcsine transformed prior to analysis.

\section{Results}

All three populations had more $\mathrm{E}+$ than E- plants (Fig. 1); $\mathrm{CW}=$ $79.6 \% \mathrm{E}+, \mathrm{BS}=71.4 \% \mathrm{E}+, \mathrm{MD}=75.8 \% \mathrm{E}+$. The frequency of $\mathrm{H}$ versus $\mathrm{NH}$ in each population was significantly different from the a priori expectation of 50:50 for all three populations. Buck Springs and MD had significantly more $\mathrm{NH}(\mathrm{P}=0.01$ and $\mathrm{P}=0.001$, respectively) than $\mathrm{H}$ infected. Clint's Well had significantly more $\mathrm{H}(\mathrm{P}=0.04)$ than $\mathrm{NH}$. Nitrate levels were not significantly different between populations (ANOVA, $\mathrm{df}=2, \mathrm{P}=0.21$ ) (Fig. 2). Clint's Well had a significantly lower percent soil moisture than other sites in May of 2006 (ANOVA, $d f=2, P=0.051$ ) but not in August (ANOVA, df $=2, \mathrm{P}=0.931$ ) (Fig. 3). Clint's Well and BS did not have significantly different plant heights (data not shown) but plants at MD were significantly taller than at both $\mathrm{CW}$ and $\mathrm{BS}$ (T-test, $\mathrm{df}=2, \mathrm{P}=0.00$ ). Only one population produced seeds (MD).

\section{Discussion}

As expected all populations contained significantly more E+ than E- plants and had different ratios of $\mathrm{H}: \mathrm{NH}$ infected plants. Our first prediction that greater infection frequencies would be found at 'poorer' habitats was not supported. Although $\mathrm{CW}$ did have the lowest soil $\mathrm{NO}_{3}^{-}$and the lowest springtime moisture levels (May 2006), it did not have significantly more $\mathrm{E}+$ plants than the other populations (ANOVA, $\mathrm{df}=4, \mathrm{p}=0.25$ ); all populations possessed more E+ versus E- plants. Since the entire Mogollon Rim area is typified by frequent droughts and ustic (frequently dry) soil regimes, it is not surprising we did not find a significant difference in $\mathrm{E}+$ frequencies between the three populations. If infection does indeed enhance host response to drought, all populations would favour E+ over Ehosts since all populations suffer drought. Perhaps the fitness response of the grass/endophyte interaction to moisture is such that the symbiosis benefits both Neotyphodium and its host during droughts but not under favourable soil moisture availability (favourable to the host) (Faeth \& Sullivan 2003). This would fit the model presented by Gomulkiewicz et al. (2003) where fitness interactions can vary from antagonistic, to commensalistic, to mutualistic in time and yet be stable, provided that mutualism is the geometric mean interaction. The fact that the population with the lowest spring time soil moisture and soil $\mathrm{NO}_{3}^{-}$also had the highest frequency of hybrid Neotyphodium, suggests that hybrids may increase host performance in relatively more stressful habitats. Hybrids were predominant at $\mathrm{CW}$, a marginal habitat in terms of soil moisture (and possibly $\mathrm{NO}_{3}^{-}$) levels at least early in the growing season. This population is not only depauperate in these key resources, but it also supports the lowest under-story diversity and abundance (pers. obs.). Thus, these initial data provide preliminary support for the BHS hypothesis as well as the existence of geographic mosaics of interspecific interactions responsive to local selection pressures. This suggests that abiotic or environmental selection pressures determine the type of interaction and favour one endosymbiont type over the other (H versus NH) at the population level (Emms \& Arnold 1997). Clearly, sampling of additional populations to increase sample size and spectrum of environmental conditions and manipulative experiments will be necessary to pinpoint whether infection, and specifically endophyte hybridisation, is a functional response to environmental factors varying at the population level.

\section{REFERENCES}

Arnold, M.L. 2004. Natural hybridization and the evolution of domesticated, pest and disease organisms. Molecular Ecology 13: 997-1007. 
Brasier, C.M.; Cooke, D.E.L.; Duncan, J.M. 1999. Origin of a new Phytophthora pathogen through interspecific hybridization. Proceedings of the National Academy of Sciences of the United States of America 96: 13589-13589.

Brasier, C.M.; Kirk, S.; Pipe, N.; Buck, K. 1998. Rare interspecific hybrids in natural populations of the Dutch elm disease pathogens Ophiostoma ulmi and O-novo-ulmi. Mycological Research 102: 45-57.

Cruzan, M.B.; Arnold, M.L. 1993. Ecological and genetic associations in an Iris hybrid zone. Evolution 47: 1432-1445.

Dombrowski, J.E.; Baldwin, J.C.; Azevedo, M.D.; Banowetz, B.M. 2006. A sensitive PCR-based assay to detect Neotyphodium fungi in seed and plant tissue of tall fescue and ryegrass species. Crop Science 46: 1064-1070.

Ellstrand, N.C.; Schierenbeck, K.A. 2006. Hybridization as a stimulus for the evolution of invasiveness in plants? Euphytica 148: 35-46.

Emms, S.K.; Arnold, M.L. 1997. The effect of habitat on parental and hybrid fitness: Transplant experiments with Louisiana Irises. Evolution 50: 1112-1119.

Gomulkiewicz, R.; Nuismer, S.L.; Thompson, J. N. 2003. Coevolution in variable mutualisms. American Naturalist 162: S80-S93.

Köchy, M.; Wilson, S.D. 2001. Nitrogen deposition and forest expansion in the northern Great Plains. Journal of Ecology 89: 807-817.

Morse, L.J.; Day, T.A.; Faeth, S.H. 2002. Effect of Neotyphodium endophyte infection on growth and leaf gas exchange of Arizona fescue under contrasting water availability regimes. Environmental and Experimental Botany 48: 257-268.

Morse, L.J.; Faeth, S.H.; Day, T.A. 2007. Neotyphodium interactions with a wild grass are driven mainly by endophyte haplotype. Functional Ecology: in press.
Rieseberg, L.H. 1995. The role of hybridization in evolution: old wine in new skins. American Journal of Botany 82: 994-953.

Rieseberg, L.H.; Raymond, O.; Rosenthal, D.M.; Lai, Z.; Livingstone, K.; Nakazato, T.; Durphy, J.L.; Schwarzbach, A.E.; Donovan, L.A.; Lexer, C. 2003. Major ecological transitions in wild sunflowers facilitated by hybridization. Science 301: 1211-1216.

Sawma, J.T.; Mohler, C.L. 2002. Evaluating seed viability by an unimbibed seed crush test in comparison with tetrazolium test. Weed Technology 781-786.

Schardl, C.L.; Leuchtmann, A.; Tsai, H.F.; Collett, M.A.; Watt, D.M.; Scott, D.B. 1994. Origin of a fungal symbiont of perennial ryegrass by interspecific hybridization of a mutualist with the ryegrass choke pathogen, Epichloë/Typhina. Genetics 136: 1307-1317.

Schulthess, F.M.; Faeth, S.H. 1998. Distribution, abundances, and associations of the endophytic fungal community of Arizona fescue (I). Mycologia 90:, 569-578.

Selosse, M.A.; Schardl, C.L. 2007. Fungal endophytes of grasses: hybrids rescued by vertical transmission? An evolutionary perspective. New Phytologist 173: 452-458.

Sullivan, T.J.; Faeth, S.H. 2004. Gene flow in the endophyte Neotyphodium and implications for coevolution with Festuca arizonica. Molecular Ecology 13:649-656.

Thompson, J.N. 1999. Specific hypotheses on the geographic mosaic of coevolution. American Naturalist 153: S1-S14.

Thompson, J.N.; Fernandez, C.C. 2006. Temporal dynamics of antagonism and mutualism in a geographically variable plantinsect interaction. Ecology 87: 103-112.

Tsai, H.; Liu, J.; Staben, C.; Christensen, M.; Latch, G.; Siegel, M.; Schardl, C. 1994. Evolutionary diversification of fungal endophytes of tall fescue grass by hybridization with Epichlö species. PNAS 91: 2542-2546. 